DOI https://doi.org/10.36059/978-966-397-199-5/105-125

\title{
SHAKESPEAREAN TEXTS AND THE IMAGE OF BARD IN THE CONTEXT OF TURKISH CULTURE
}

\section{Iryna V. Prushkovska}

\section{INTRODUCTION}

The essence of the study is to analyze, synthesize, systematize information regarding the functioning of Shakespeare's creativity in Turkish culture, incorporating exploration, reception, and interpretation of Turkish-language literary works already performed by the author of this study, grouping separate areas of revealing the influence of The Bard of Avon to the Turkish cultural sphere.

As we know, each nation has an inherent identity, particularly in culture. The widespread promotion of cultural achievements is necessary for the full functioning of the people at every historical stage; it preserves it, defines the identity between other peoples, which is a kind of regulation of socio-cultural processes. However, the processes of interaction between nations and ethnic groups happen and predetermine the synthesis of the cultural and artistic process, enrich national cultures. The same thing happened with the Ottoman state, on the territory of which different peoples with different languages and denominations lived, and also, under certain political and historical conditions, interaction with the West took place. One of the best assets of such interaction is the interaction of English literature and culture with Turkish. The Ottomans became acquainted with English literature through Shakespeare's work. The Shakespearean context has an important ideological, formative, aesthetic function in Turkish culture. Due to the numerous translations and the presentation on the Turkish stage of the work of the great English dramatist, Turkish culture has at its core a solid "brick" of English culture.

First of all, it is worth noting the importance of the influence of Western culture in general on the traditional, centuries-old culture of the Ottoman state. Touching on certain historical points, the full perspective of the entry of Western models of art into Turkish literature, theater, and media sphere will be drawn. So, the influence of Western tendencies became significant at the beginning of the 19th century in the Tanzimat period (the era of Ottoman reform). Previously, only the canons of Oriental literature, mainly Arabic and Persian, influenced the 
development of Turkish culture. The connection of the Ottoman Empire with Europe, first of all with France, took place even before the reforms of 1839 by Suleiman Aga and Yirmisekiz Celebi Mehmet Effendi. Signed between France and the Ottoman state in 1740, the so-called "capitulation" document for a long time was the basis of privileges for France: the French were given the right and freedom to trade in the territory of the Ottoman state under the full protection of the Sultan, the French consuls had judicial power, there were no restrictions on religious and cultural plans.

Shakespeare's creativity is characterized by a "wonderful aura of unreasonable mystery and magical appeal", despite the vast amount of scientific exploration, theatrical interpretations, imitations, stylizations, adaptations. Shakespeare's word became a part of Turkish culture and literature, in particular with the formation of the Turkish author drama of the European model (after 1859), with the formation of genres such as comedy (Independent Guest, Chatting Hairdresser, Beauty and Tragedy by Ali Haidar Bey (1836-1914); Homeland or Silistra, Black Trouble by Namik Kemal (1840-1888), modeled on genre clichés of Western European drama.

\section{Empathy for Shakespeare through translations}

The stage of acquaintance of Turkish society with the English playwright was primarily due to the active work of translators. Considering the powerful influence of the French Revolution (17891799) on the Ottoman political and, above all, cultural system, the popularity of French language and literature in the Ottoman state, it is worth noting that Shakespeare's first work, which was included in Turkish dramaturgy, was Othello, translated (1870s) into Turkish by Hassan Bedreddin Pasha and Manastirli Mehmet Rifat. Subsequently, three parts of Hamlet appeared, translated from French by Mehmet Nadir Bey, mathematics by education. Subsequently, Nadir Bey presented to the Turkish reader forty-two sonnets of Shakespeare (1887-1888). Under certain political conditions, Shakespeare's works did not spread to the Ottoman states during the first stages of cultural reform (from 1839). According to historical sources, the Ottoman ruler Abdulaziz (18301876) was concerned with the integrity of the country, so any attempt to

${ }^{1}$ Торкут Н. М. Шекспірознавчий дискурс XX століття: специфіка і тенденції. Ренесансні студії. Запоріжжя, 2003. Вип. 9. С. 73. 
destroy this unity was punished by him rather cruelly. During his reign, the translations of Shakespearean dramas, which involved the murder of members of the ruler's family because of a lust for power, were negatively regarded ${ }^{2}$.

With the coming to power of Abdulhamid II (1876-1909), the situation with the development of the new dramaturgy was worsening. Literary works were subjected to severe censorship, actors were thrown into prisons, and theaters were closed and burned at the behest of the sultan $^{3}$. But despite the political harassment, the Turkish drama, albeit slowly, paved the way.

Thus, in 1884-1887 the translations of the Ottoman scholar, Orikagasizade Hassan Sirri Bey, Shakespeare's drama The Merchant of Venice and The Comedy of Errors were published. In 1886, a civil servant, Mihran Boyadzhian, translated the plays Romeo and Juliet, The Two Gentlemen of Verona, and the same year published a separate publication in the Jivelekian publishing house. In 1912, the tragedy Othello (published by Manzumi Efkar) was translated into English by M. Boyadzhi, although the translation was completed as early as 1896 , but the publication was not authorized ${ }^{4}$ Abdulhak Hamit Tarhan (1852-1937) actively worked on the adaptation for the Turkish scene of the works of Shakespeare and Hugo: Ashber, Ilhan, Sensitive Girl 5 .

Politician, physician, public figure, active revolutionary Abdullah Dzhevdet (1869-1932) in 1908-1910 actively translates Shakespeare (Julius Caesar, Hamlet, Macbeth, Romeo and Juliet). A. Dzhevdet's fascination with Shakespeare's work began in medical college. In 1884 he wrote a poem that reflected the author's emotions from reading Shakespeare's plays ${ }^{6}$. Turkish researcher Sevda Ayluchtarhan states that A. Dzhevdet's interest in English literature is not a mere coincidence ${ }^{7}$. In her opinion, he regarded the British as a superior race, and everything concerning the Anglo-Saxons was a priority for him. In this way, he differed sharply from his contemporaries, since at the end of the

${ }^{2}$ And M. Osmanlı tiyatrosu kuruluşu gelişimine katkısı. Ankara, 1976. S. 171

${ }^{3}$ Aldağ Z. Ş. Türk tiyatrosunda Kurtuluş savaşı. İstanbul, 2008. S. 27.

${ }^{4}$ Ayluçtarhan S. Dr. Abdullah Cevdet's translations (1908-1910): The making of materialist "culture repertoire" in a resistant ottoman context: Thesis master of arts in translation studies. İstanbul, 2007. S. 38.

${ }^{5}$ And M. Osmanlı tiyatrosu kuruluşu gelişiminine katkısı. S. 173.

${ }^{6}$ Ayluçtarhan S. Dr. Abdullah Cevdet's translations (1908-1910). S. 40.

7 İbid. S.42. 
nineteenth century. In Ottoman society, the palm of primacy was occupied by French culture and literature in particular (from 1860 to 1896, 79 dramas were translated from French, while only 8 were translated from English $)^{8}$. A co-organizer and a member of a secret union that fought against the dominant ideology of the Sultan, A. Dzhevdet tried different ways of the anti-sultan movement, including literary translation. When translating Shakespeare's dramas, A. Dzhevdet was primarily driven by the desire to convey to the Ottomans European values and to oppose the sultanate, rather than the desire to create a translation masterpiece. Perhaps this is explained by the fact that among the literary experts of the time, A. Dzhevdet's translations were ambiguous. Thus, in the memoirs of the famous writer Suleyman Nazif, we come across a sharp criticism of A. Dzevdet's translations: "Nazif, I am very scared that I can die without translating Shakespeare," A. Dzevdet refers to a friend. "On the contrary, I'm afraid you will die after you translate it all. Everyone thinks that Shakespeare's work is immortal, and you make them dead by your translations"9. Despite this, A. Dzevdet's translations have their place in the history of Shakespeare's entry into Turkish culture, since they are the first, numerous. A. Dzhevdet was delighted with the works of the Bard of Avon, tried to present as much as possible from them to Turkish reader and viewer. And this is his great merit. One of the drawbacks of his translations is the rather complicated language (so much so that his Ottoman texts were first written in Latin and published in Turkey only in 2017), as well as his "presence" in Shakespeare's works. As a translator, he should dissolve into the translation, transposing the original as much as possible, but his style is very noticeable in translations, which sometimes makes him and Shakespeare distinguish ${ }^{10}$.

An important role in the introduction of the Ottomans with the work of Shakespeare played a translation of the Turkish work of Victor Hugo William Shakespeare. According to Turkish researcher Inci Enginun, this book had an even greater impact than single translations of

\section{S. 29.}

${ }^{8}$ Enginün İ. Tanzimat devrinde Shakespeare: Tercümeleri ve tesiri. Istanbul, 1979.

9 Avcı Z. Şekspir'den Shakespeare'e: Üstadın Anadolu macerası. BBC Türkçe, 7 Mayls 2014. URL: http://www.bbc.com/turkce/haberler/2014/05/140507_shakespeare_ anadolu_zeynep_avci.

${ }^{10}$ Torbalı Ö. Y. Çeviri ve tarihsel hafıza. Çeviribilimde Güncel Tartışmalardan Kavramsal Sorgulamalara Monografi. İstanbul, 2018. S. 244-245. 
Shakespeare's works from French to Turkish ${ }^{11}$. The weakening of political oppression and the active Europeanization of Turkish society contributed to the creation of theatrical unions and theaters. Finally, it was time to introduce Shakespeare on the Turkish stage. Thus, in 1912, the famous Turkish actor Muhsin Ertugrul, on the stage of a local Turkish theater, presents viewers of Shakespeare's play Hamlet in his translation and the lead role. It is worth saying that Hamlet in the performance of Muhsin Ertugrul had great success on the stage of Turkish theater. Original costumes, great actors (Ismail Galip, Shazie Hanim, Bedia Hanim), a well thought out script - all contributed to the success, every day during half a month all tickets were sold and seats in the theater were filled with grateful spectators ${ }^{12}$.

In 1914, the Daryulbedai Institution was founded, which was later renamed the Istanbul Local Theater. The institution aims to teach theatrical art and present works by both Turkish and European authors to a wide range of viewers ${ }^{13}$. Kamil Riza - one of the first students of Daryulbedai traveled with his troupe almost all Anatolia with the performance Revenge of the Arab based on the play of Shakespeare Othello. Kamil Riza even nicknamed himself after the name of the character he represented many times on stage - Othello Camil.

We suppose that the functioning of the translated works of Shakespeare in the artistic consciousness of the Turks was harmonious, since the use of allegories, vivid metaphors in the English text very much resembled the language of poets of Indian style (Sebki-Hindi), close to the Turks. After all, the main features of the Indian style are the sophistication of metaphor, original comparisons, manner, complex symmetry of images, fantastic as an artistic reception, new meanings and interpretations of life realities, likeness, hint, symbols ${ }^{14}$.

In favor of the assertion that Shakespeare's figure gradually echoed in Turkish society in the first half of the twentieth century, the fact of the emergence of single works, poetic works devoted to the great national poet of England. In 1921, the poem Shakespeare appears from the pen of the famous Turkish poet Tevfik Kolayli (Neyzen Tevfik, 1879-1953):

\footnotetext{
${ }^{11}$ Enginün İ. Türkçede Shakespeare. İstanbul, 2008. S. 11.

12 Karataş H. Türkiye'de Hamlet olmak. Arka Kapak Kitap ve Kültür dergisi. Mayıs 2018, sayı 32. S. 35.

${ }^{13}$ Çeşitli İ. II. Meşrutiyet dönemi Türk edebiyatı. Ankara, 2007. S. 235.

${ }^{14}$ Прушковська I. В. «Краса і Любов» Шейха Галіба (до проблеми індійського стилю у турецькій літературі) [Монографія]. Київ, 2008. С. 34-37.
} 
Şekispir'in bütün asarına değil, birine

Feda imis Britanya o hikmet efserine.

Ne muhteşem, ne derin bir mehabet-i takdir,

Yeter bu İngiliz 'in ilme aşkını tasvir.

Revân eder acı sözlerle tayf-ı hikmetini,

Bu serzeniş ile sezmiş vatan muhabbetini

Britain is leaning toward creativity

This crown of knowledge.

What a wonderful praise, what a love of the British for science

And it melts in the depth of time

This sadness and love for the motherland.

In 1934 Jenap Shahabettin publishes the book William Shakespeare, which first presents the biography, life and career of Shakespeare in Turkish ${ }^{15}$. Representation of Shakespeare to a Turkish reader/viewer was done by well-known Turkish writers: Halide Edip Adivar, Sabahattin Eyuboglu, Ulku Tamer, Can Yucel, Mina Urgan, Berna Moran, Talat Sait Halman. In particular, Halide Edip Adivar (1941), Orhan Veli Kanık (1949), Sabahattin Eyüpoğlu (1965) translated Hamlet, and each translation was distinguished by own interpretation of the known text.

In the '60-'70s of the 20th century Turkey is experiencing a decline in interest in Shakespeare's creativity through the renewal of the national drama model, a radical rethinking of traditional cultural values and the weight of national identity. In time, the ideas of B. Brecht's epic theater.

The events of 1980 (the military coup in Turkey) became the starting point for political and cultural changes that provoked the acquisition of "blocked character" literature and contributed to the growing of interest in world dramaturgy: Shakespeare (King Lear, Hamlet), C. Goldoni (The Servant of Two Masters), M. Gogol (The Government Inspector), E. Ionesco (Exit the King). At this time, Turkish play writers resort to the language of allusions, trying to identify artificially and outline the current situation. In that period Turkish literature and dramaturgy, in particular, are experiencing a "thematic" crisis caused by political and economic problems. Censorship, repression, bans have spread not only to the political sphere but also to the cultural

${ }^{15}$ Avcı Z. Şekspir'den Shakespeare'e: Üstadın Anadolu macerası. 
sphere. The government restricted any expression of freedom of thought, so it banned many writers and even tried to strike out such words as "revolution", "nation", "organization/union", etc. ${ }^{16}$. September the 12 th is called "the bloodiest period in the life of the republic" when there were attempts to "completely reshape Turkish society" through torture, repression, oppression, high-profile court cases ${ }^{17}$.

Complex political conditions have displaced dramatic works that have raised important social issues, closed theaters, released actors and theater executives. In an atmosphere of constant prohibitions and obstacles, artists lost their ability to create. Only private theaters held positions, but given the material damage, they favored the plays of one actor. Theaters lost viewers who gradually switched to television programs ${ }^{18}$. Such a dramatic change in the repertoire vector, on the one hand, demonstrated the "escape" of the playwrights from real events into the world of allusions, caused by the inability to openly express their opinion on the political situation in the republic, on the other hand, such a condition contributed to the expansion of theatrical repertoire, an increase in the number of translations into Turkish world masterpieces, it was an opportunity to take on the experience of famous playwrights once again.

Turkish theaters returned the play Hamlet with new interpretations. In 1997, on the stage of the Kocaeli Municipal Theater, the director Ishil Casapoglu presented his vision of Hamlet in full: the play lasted six hours, as the director felt it necessary to leave the text unchanged and without cuts. Despite the length of the play, it was a success and positive reviews of theater critics ${ }^{19}$.

Shakespeare's A Midsummer Night's Dream was first introduced to a Turkish reader in 1936 by Nareddin Sevin ('Yaz ortasinda bir gece rüyası'). Almost fifty years later, a translation by Can Yucel (1981) and a translation by Can Dogan (2005) was published. The Turkish version of Shakespeare's famous comedy, translated by the Turkish poet Can Yucel (1926-1999), is of interest from the standpoint of originality and coherence with the concept of "artistic translation". As a writer, Can

1612 Eylül ve Edebiyat. 12.09.2009. URL: httрділь://www.sabitfikir.com/ dosyalar/12-eylul-ve-edebiyat.

${ }^{17}$ Türkeş A. Ö. Darbeler; Sözün Bittiği Zamanlar. Hece Hayat, Edebiyat, Siyaset. İstanbul, 2004. Özel Sayıs1: S. 90/91/92. S. 430.

${ }^{18}$ Şener S. Cumhuriyet'in 75 yılında Türk tiyatrosu. Ankara, 1998. S. 223.

19 Karataş H. Türkiye'de Hamlet olmak. Arka Kapak Kitap ve Kültür dergisi. Mayıs 2018, sayı 32. S. 35. 
Yugel is known for his colorful, vernacular, which he rewrote on Shakespeare's comedy, replacing the author's style with his own. Turkish literary critics (O. Duman, J. Ozkaya, D. Ustter), analyzing C. Yucel's Spring Equinox, agree that he created his play based on Shakespeare's works, which is only partly based on original ${ }^{20}$. At the same time, the author of the play is confirming self-presentation and self-positioning as a translator, thereby directing us to a comparative analysis of the original and the second work. First of all, it is worth noting the structural discrepancy between the original and the translation: the Shakespearean play has 5 acts in two scenes, while C. Yucel's comedy consists of two actions (5 and 4 scenes), respectively, and one part of the play is reduced by reducing individual dialogues, scenes.

The plotlines of the original and the second creation are almost unchanged. However, as noted, C. Yucel replaced the Shakespearean style of writing on his own, which brings the language of the heroes closer to the Turkish language as much as possible, allowed himself and certain substitutions in the personal sphere. The hero of the central plot motif Lysander, in love with Germia, C. Yucel transforms into Iskender (Alexander the Great), elves - into gins, bringing German mythological connotations closer to Turkish ones. In the play of C. Yucel, heroes with ancient names sing Turkish folk songs (Bülbülün ninnisiyle, Güllerin nefesiyle, E yavruma, e e e e $)^{21}$, speak as commoners, their language is replete with Turkish constant expressions, sayings, colloquial vocabulary (Hadi firla, Filostarta; bu namuzsuz da alem etti, kallem etti, kızımı kendine benzetti; cicibici, incik-boncuk, takuldak-bon bon; kulusun, avucunda onun bir tutam balmumusun; Dimitri denen atsız süvari; akıl defterime yazmıştım; kırklara karışlyor sevgi; ă̆zını öpeyim, Hermiya! Fesüphanallah! $)^{22}$. C. Yucel successfully incorporates into the text canvas and Turkish folklore, cultural peculiarities, bringing the work as close as possible to the Turkish recipient (Philostratus: "And the wedding will last forty days and forty nights" ${ }^{, 23}$; Theseus: "On this Path of the Sacred pilgrimage ... "24;" The first act ends with the Mendelssohn march “25.

20 Duman O. Bir Yaz Gecesi Rüyası ve Bahar Noktası'nın çeviri açısından karşılaştırılması. Çeviriblog. URL: https://www.ceviriblog.com/2016/08/30/bir-yaz-gecesiruyasi-ve-bahar-noktasinin-ceviri-acisindan-karsilastirilmasi/.

${ }^{21}$ Shakespeare W. Bahar Noktası. Türkçe söyleyen Can Yücel. İstanbul, 1981. S. 28.

22 İbid. S. 29.

23 İbid. S. 8.

24 İbid. S. 9. 
Despite the "indulgence" of the Turkish style of Shakespeare's play A Midsummer Night's Dream by Can Yucel, the translation succeeds in retaining, albeit indirectly, the author's intention of presenting a unique combination of the real and the fantastic, the lyrics and the humor. C. Yucel, by transforming the text of the original, has achieved the preservation of the main events of the comedy and symmetrical gradations of tension. In general, C. Yucel managed to attract the attention of the Turkish community to the works of Bard from Avon, given the popularity of the scene of the Spring Equinox in Turkey. The interest of Turkish writers in the work of the great Bard is further evidence that Shakespeare's works are an inexhaustible source, with no national or religious boundaries.

\section{Shakespeare's word in Turkish dramaturgy}

In addition to the stage adaptations of Shakespeare's works, for the first time, the works of the Bard of Avon begin to function in Turkish literature as an intertext. Thus, the famous Turkish playwright Bilgesu Erenus (1943) in the play Joy of Pain (1991) develops one of the traditional themes of world literature - the theme "man at the turn of history", his self-identification, moral choice - and deliberately appeals to Shakespeare's artistic experience understanding this problem.

The plot is based on the events of September 12th, 1980 and their impact on the fate of four young men. For the first time in the history of Turkish dramaturgy, this work presents an extensive storyline: several storylines are developed in parallel, related to the fate of each of the characters, who have points of intersection at the same time. The play begins with an intrigue around a photograph of three young men. All three are for the democratization of society, for change of political institutions. The position of the fourth man, a filmmaker is unknown. This is also one of the new techniques introduced by B. Erenus: an intrigue that is not revealed until the end of the play. Images of historical time conditionally divide the work into two parts: before the military coup and after. This makes it possible to incorporate elements of the detective into the work: the girl who finds the photo card is trying to find out what happened to those young people as their life turned out. The intersection of each of the storylines is dramatic, as the military events in Turkey have changed the lives of the people forever. The first young man turns into an antihero,

\footnotetext{
${ }^{25}$ İbid. S. 38.
} 
becoming, after the known events, a richer man who is ready to sell the soul for dollars. The second cuts through his veins without suffering abuse in prison and the third gets used to alcohol, realizing that all his efforts to produce a revolutionary magazine have come to naught. To create a message to the younger generation and to "soften" the tragic ending, the author develops an optimistic version: the girl tries to return dreams and hopes to a third of the young men, believing that it is easier to cure the soul-sick of alcoholism than to make the rich regain consciousness. The play is not only contemporary in content but also nationally accentuated, and its plot is linked to a key moment in Turkish history.

In The Pleasures of Pain, B. Erenus offers several plausible behavioral patterns (passivity, aggression) in a political crisis, and at the same time creates a symbolic image of the girl as the highest judge of the future, enriched by Shakespeare's vital wisdom. But this girl is a Turk, who witnessed a military coup in Turkey in 1980, and who seeks to help her nation stand on the path of destroying values. The play Antonius, Cleopatra by Orhan Güner (1992) is an allusion to the tragedy Antony and Cleopatra by Shakespeare. Antonius of $\mathrm{O}$. Güner is a great conqueror, in love with Cleopatra, speaks at least two Western languages - French and English. A somewhat ironic image of the "heroic" commander is formed by widely known communicative cliches in both languages:

Cleopatra: Start you.

Antonius: No, please.

Cleopatra: I beg.

Antonius: Ladies first! ${ }^{26}$.

Both Antonius, Cleopatra, and even Caesar, despite their recognizable names, are masks that hide the images of contemporaries. Yes, Caesar cares about the state of the Turkish theater, dramaturgy, trying to convince others of the importance of maintaining a high level: "Caesar: Hold on, you can't kill the viewer. Do you think it's easy to educate real art connoisseurs today? These are the kind of whimsical people who can enjoy something interesting everywhere: in supermarkets, in stadiums, and on $T V^{, 27}$. Orhan Güner's play can be described as a postmodernist play in tragedy that lacks a well-defined conflict, acuteness, and deep philosophical content. In 1990, Necati Jumali introduces fragments of world intertext, including allusions to

\footnotetext{
${ }^{26}$ Güner O. Toplu oyunları 1. İstanbul, 1996. S. 90.

${ }^{27}$ İbid. S. 92.
} 
Shakespearean tragedies, into the character's replicas, thus revealing the literary atmosphere of the depicted era, extending the temporal limits of perception.

Kemal (To Melik): How are you? Why are you standing on the threshold, not passing?

Hey, Melika, Melika

Why are pockets leaky?

(Laughs) Is it better:

Hey, Melika, Melika,

Who confused you? ${ }^{28}$

In the preface to most of his works, the famous Turkish playwright M. Baydur (1951-2001) expresses his gratitude to both Turkish artists and representatives of the world culture, in particular Shakespeare, thus outlining his proofreading and noting that he is grateful to the writers of the world for their enormous influence on his literary writings: "I express my sincere thanks to Emo, Suat Nafiz, Oguz Atay, Nebi, Nafi, Nietzsche, Carl Orff, Van Gogh, Omer Kirshan, Cervantes, Orhan Veli, Metin And, Aziz Nesin, Shakespeare. If it were not for their heritage, there would be no play 'Lemon', 29 .

Ozdemir Nutku's Turkish drama Call Me William (2010) reveals the theme of psychological trauma and traumatic memory, based on stories from the life of the protagonist, Oscar, who conveyed throughout his years the love of Shakespeare's creativity and desire to be a part of his dramatic world. Traumatic memory of the protagonist is formed in childhood and adolescence: he did not know the mother's love, because his mother died in childbirth, he kept an image of his father, who arranged for him to work in a circus cleaner, he blamed himself for being fascinated by the scene and works of Shakespeare: "After three years of cleaning up the crap, I was offered the job of Assistant of the Chief Clown Olof Bab. Olof had so many books about theater. I read and re-read them every night. It was then that I read Shakespeare. I would rather not read. Inside, I had a terrible desire to be on stage. And this desire grew every day" ${ }^{\prime 30}$. Over time, Oscar manages to get into the theater and play his first role - Oswald of King Lear. However, Shakespeare's admiration gives rise to the next trauma, the most decisive in Oscar's private life - the

\footnotetext{
${ }^{28}$ Cumalı N. Bütün oyunları 2. İstanbul, 2004. S. 636 .

${ }^{29}$ Baydur M. Tiyatro oyunları. İstanbul, 2009. S. 12.

${ }^{30}$ Nutku Ö. Bana William Deyin. İstanbul, 2011. S. 15.
} 
rejection of a loved one, the inability to start a family, the doom of loneliness. The situation is rather banal: Oscar asks his beloved Lisa's father for her hand. Father agrees but if Oscar leaves the theater and finds a decent job. The trauma of the situation is exacerbated by the fact that, after giving up his beloved, Oscar will wait for forty years for his role in Shakespeare's plays, unable to fulfill the dream of a lifetime. Dramatic and traumatic is the opening finale of the play: Oscar is offered a new role at the end of his life - the role of the clown from King Lear: Theater director says to Oscar "Can I call you William? I have a surprise for you. From now on you will play the clown. We are waiting for you at the rehearsals of the performance ... The actor is not moving, he is frozen in place. It is darkness ...",31.

Thus, the traumatic memory of the protagonist is the result of the preservation and reproduction of the traumatic experience, which consists of memories of traumatic events. The ability to comprehend traumatic events, to live them consciously saved the hero from a post-traumatic stress disorder and the love of Shakespeare's work added decisive meaning to the continuum of life.

Summarizing the need to improve the perception of the Turkish youth of dramaturgy, the need to educate the Turkish young generation on the examples of national literature and centuries-old world masterpieces, continuing the centuries-old traditions of the world interpretation of Shakespeare's work, New York, Shakespeare's Children's Theater, Turkish playwright, actor Nafiz Uslu transforms Shakespeare's prose into a small play for children (67 pages). In a preface to The Storm of Nafiz Uslu, psychologist educator Umit Görgül states: "There is no drama for children in Shakespeare's work. Aware of his great responsibility, Nafiz Uslu reworked Shakespeare's play into a play for children, thus creating the opportunity for children to know the masterpieces of the Bard of Avon" ${ }^{32}$. It should be added that the choice of N. Uslu was not accidental. After all, Shakespeare's The Tempest, in comparison with his other works, is maximally saturated with elements that easily arouse children's imagination: a fascinated island, travel, a magician, a spirit, a loving couple, and also has a strong didactic basis, which touches on issues of good and evil, fantasy and reality, comic and serious. Conscious of the complexity of transferring a large volume of a multilayer original work to

\footnotetext{
${ }^{31}$ İbid. S. 49.

${ }^{32}$ Uslu N. Firtına (W. Shakespeare). Çocuk oyunu. İstanbul, 2015. S. 8.
} 
another plane, $\mathrm{N}$. Uslu takes as its basis a separate storyline The Tempest, hyperbolizing it. The exposition of the play by Uslu informs the reader/viewer at the beginning of the action (the Prospero monologue addressed to Miranda, in which he recounts the story of his exile). The action begins with Prospero on the remote island freezing in the air because of a failed use of magical power and asking for Ariel's help. Upon seeing the ship from afar, Prospero asks not only to help him land but also to make sure that the ship's passengers are on the island. Ariel's storm brings Alonzo (King of Naples), the main culprit of Prospero's exile, and his son Ferdinand. The organization of events in the work is devoid of intrigue, the plot unfolds in four acts. The development takes place through Prospero's conflicts with Ariel, Ferdinand, Alonzo, and Caliban. Prospero's meeting with Alonzo, the return of his temporary memory to the King of Naples, and his plea for forgiveness are the culmination of the drama of N. Uslu. The last stage in the development of the conflict is Prospero's decision: forgive everyone, give freedom to Ariel, bless Miranda for marriage and return home. There is only one test scene in the Turkish Storm - Ferdinand's detention and his hard work. There are no tragic episodes involving Sebastian and Antonio, Stephano and Trinculo in the play. The meaning of N. Uslu's drama is lacking in important information, such as geographic locations (Tunisia, Bermuda), mythical elements (spirits, except Ariel, deities). However, special attention was paid to the romantic relationship between Ferdinand and Miranda. Simplifying the plot of N. Uslu's play accordingly leads to a decrease in the number of actors. Prospero, Ariel, Alonzo, Ferdinand, Miranda, and Caliban are the main characters of the Turkish Storm. The image of the Turkish Prospero is distant from the original work, and the readers/viewers are incapable of great magic, a somewhat rude, awkward elderly man: Prospero: "What about me? How clumsy I am, what a shame. I can not use simple magic ... I have no strength. I already lose the ability to charm. I was not like that before ... Help! .. Help! Arielle!!! "33 It is not worth mentioning about the nobility and Christian forgiveness that Shakespeare laid in the image of the protagonist, analyzing Prospero of N. Uslu: "Where are you, Ariel? Where are you, dirty gin?...", " "What the hell are you munching on, Arielle?"35," "Your tongue became

\footnotetext{
33 İbid. S. 12.

34 İbid. S. 13.

35 İbid.S. 14.
} 
something long", "Shut up, don't confuse me"36, "Ah, thank you, but quickly do what I say to you until I have roasted you like a chicken", "Ah, you are mad"37. The choice of the author, namely - the rude image of Turkish Prospero, which emerges because of his behavior and replicas, is difficult to justify. It is unlikely that such a method should be used to educate Turkish youth on the examples of world literature, as N. Uslu says. We can only assume that N. Uslu transferred Shakespeare Prospero's attitude to Kaliban to Ariel's attitude in the Turkish version. However, if Shakespeare's such behavior of the protagonist is explained by the inability to change the rude nature of Caliban (who also encroached on Miranda's honor) only through the methods of education, then in the Turkish Storm Prospero's attitude to the spirit, which helps him all over, is puzzling. At the same time, due to certain replicas from the play, it seems that the Turkish author implicitly expresses his attitude towards the political leaders, whose collective image is Prospero. By the way, this practice of hidden politically colored context was intensified in Turkish dramaturgy in the totalitarian 80ts of the 20th century, but it was not the first time that it was applied in children's drama. Miranda, trying to find out who was to blame for the storm, questioned both her father and Ariel whether the spells were used and for what purpose:

Miranda: You couldn't help but hear this storm. Probably, if you are so calm, then one of you put your hand up.

Ariel, Prospero: No, what are you talking about?

Miranda: If not for the hand, then at least the finger has gotten into the thing.

Prospero: How do you know who and what finger mixed this porridge with, you ask, as if in a child's play with palms: "I gave it to porridge, I gave it, and I didn't give it. Who did not give the porridge, he became angry and began to scream, "And me?".

Ariel: This is usually the little finger. He is small, he needs someone to feed him. Well, the inferiority complex, inferiority - because of the short growth.

Miranda: It's clear! Father, why, why? ${ }^{38}$.

In the Turkish 'Storm', there is no clear distinction between the characters in the positive and negative, each character has ambivalent

${ }^{36}$ İbid.S. 17.
${ }^{37}$ İbid. S. 18.
${ }^{38}$ İbid.S. 26. 
character traits. Yes, Prospero in the play finale keeps his words and gives Ariel his will, forgives his enemies, expresses his desire to continue to educate Kaliban, avoids rude things. Ariel - the only character who has a talent for true magic, forcibly helps Prospero retaliate against the abusers, he has a poignancy of words and reason. At the same time, his remarks contain a mockery of the characters of the drama and manifestation of arrogance and arrogance. Ariel also acts as the narrator:

Appears on stage. Watching the turmoil on the island, one movement seems to stop the action. "That's better. Hold your breath for a while. I have to think. Let's see what's up. Prospero wants to take revenge on Alonzo for forced exile; Alonzo lost his memory, though he remembers it a little; Caliban proclaims himself king on this occasion; Miranda and Ferdinand fall in love with each other. Ariel was destined to unravel it all. But first, we confuse even more, and there we will see"39. Alonzo does not arouse harsh criticism over the offense, and his half-insane state due to memory loss and head trauma causes sympathy and thought about the inevitability of punishment. However, he is a semi-comic hero, his childish sweet cues, the songs entertain: "My lean camel died of obesity. He died neither on earth nor in heaven. An hour before sunset, he died in the morning", "I sing songs / I rejoice and I jump / Where will I see the flower? I collect honey there / La la la, I work" "4I. Miranda is the epitome of beauty, youth, kindness. However, the heroine has a royal temper:

Prospero: My dear daughter, now you understand why I caused the storm?

Miranda: No, I still don't understand.

Ariel: This baby is in no hurry.

Miranda: I'm talking to my dad ... Dad, tell something to this gin ... ${ }^{42}$.

Prospero: They ended up on this island for me to punish.

Miranda: That's good, Dad, so they should ${ }^{43}$.

Ferdinand is a romantic image, a prince who, for love's sake, is ready to be tested by the common man. But Ferdinand has one flaw - he's a coward. Suddenly, when he meets with Caliban, he escapes with a cry:

\footnotetext{
${ }^{39}$ İbid. S. 55.

${ }^{40}$ İbid. S. 47.

${ }^{41}$ İbid. S. 57.

42 İbid. S. 8.

${ }^{43}$ İbid. S. 29.
} 
"Mom, save!"44. Caliban, despite the instability of character, indifference, ingratitude, brutality, has a "pure heart"

Despite the inevitable simplification of the plot and the omission of many central scenes, N. Uslu manages to preserve, albeit indirectly, the philosophical content of the original. The young Turkish viewer has a chance to admire the world of the classics, to immerse himself in the content, to express himself in the views on the vital issues of power, freedom, friendship, betrayal. N. Uslu's dramatic work has a didactic focus, creates an atmosphere of fairytale that contributes to the happy resolution of the tragic conflicts. In general, Nafiz Uslu managed to attract the attention of the Turkish youth to the works of Bard of Avon.

\section{Shakespeare in the media space of Turkey}

Today, Shakespeare's works have firmly entered the scientific and media discourse of Turkish society. There are explorations of Shakespeare's works on Turkish literature (O. Esemenli, H. Yazidzhi, M. K. Chalishkan, A. Dagistani, C. Panther), translation studies (N. Demirkol, M. S. Sarma, N. Ichoz), comparative studies (M. Ozturk), psychology (F. Artukoglu, M. Koch). In today's Turkish media space, Shakespeare is first and foremost a symbol of English culture (his images are actively used in advertising), as well as the author of the difficult life dilemma of "To be or not to be - that is the question". Given the multifaceted functioning of this expression in the Turkish media space (in newspaper articles, blogs, news, advertisements of a social, political character, advertising of goods and services, fiction, periodical, philosophical literature), it is recognizable and culturally marked ${ }^{46}$. For example, social advertising on the October 26, 2017, Haber aramizda news portal reads: "Whether or not to be vaccinated against the flu is the question,"47.

The use of Shakespeare's statements in the professional field by Turkey's bloggers, identification with the young modern generation of historical figure characterizes the linguistic and cultural space (Blog of NETVENT Marketing Consulting Company "Whether to be a YouTube

S. 10 .

${ }^{44}$ İbid. S. 55.

45 İbid. S. 65

${ }^{46}$ Enginün İ. Tanzimat devrinde Shakespeare: Tercümeleri ve tesiri. Istanbul, 1979.

${ }^{47}$ Grip aşısı olmak ya da olmamak, işte bütün mesele bu! 27 Ekim 2017, Cuma. URL: https://www.haberaramizda.com/grip-asisi-olmak-ya-da-olmamak.html. 
or not - that is the question"). Hamlet's monologue does not go beyond even the football field of modern Turkey. For example, in the sports commentary in the Akdeniz Manshet newspaper on March 5, 2019, regarding the critical situation around the match between Galatasaray and Antalyasport, it sounds eternal "To be or not to be -90 minutes will decide the fate of teams"

The Justice and Development Party (AKP) is a powerful political party in Turkey. Its symbol is a glowing lamp used on a poster 2013 (election period) with the inscription: To be or not to be? Here's the thing!. Shakespeare's semiotic heritage is palpable and one of the most common areas of Turkish business - gastronomic. The Shakespeare chain of restaurants in Antalya, Alanya, Diyarbakir, Bursa, Izmir, Kayseri, Kemer, Manavgati is replete with the names of the heroes of the great Bard plays. The menu includes dishes with Shakespeare's allusive names: "Romeo" - the main meat dish with vegetables and soy sauce; "Juliet" is a chicken breast with vegetables; from the desserts - "Othello" chocolate pudding, brownies, cocoa, and biscuits ${ }^{49}$.

Turkish researcher Zeynep Avci in her article "From Shakespeare to Shakespeare: Anatolian Adventures of the Master of the Word" (2014) cites interesting facts related to the functioning of Shakespeare's work in Turkish dramatic and television spaces: Ayla Algan - one of many actresses. For example, from 1962 to 1965, she played both Hamlet and Ophelia at the Istanbul Local Theater, directed by Muhsin Ertugrul ${ }^{50}$. In 1976, a film by Metin Erksan's Woman Hamlet or the Angel of Revenge, starring Fatma Girik, appeared on television. The film has been recognized both at home and abroad through its participation in international film festivals ${ }^{51}$. The plot of the film is set in Turkey, all the characters bear Turkish names, except for the main one - Hamlet-woman. The movie is full of irony, absurd scenes, dramatic and comic scenes.

Romeo and Juliet's story is also reflected in the Turkish cinema. The films of Orhan Aksoy Bitter Life (1973), Kartal Tibet Children of Paradise (1977), Remzi Jöntürk Once Upon a Time (1982) are based on Romeo and Juliet's love story, but none of the films mentioned, according

48 Varlı Ö. Zorlu 90 dakika iki takımın da kaderini belirleyecek Olmak ya da Olmamak. AkdenizManşet. 5.03.2019. URL: https://www.akdenizmanset.com.tr/spor/ olmak-ya-da-olmamak/157138/.

${ }^{49}$ Shakespearebistro. Menu. URL: http://shakespearebistro.com/.

${ }^{50}$ Avcı Z. Şekspir'den Shakespeare'e.

${ }^{51}$ İbid. 
to film critics does not convey the full depth of Shakespeare's creative idea.

Bulent Emin Yarar is the only Turkish actor to have played all the roles of Hamlet in one play (2003, Istanbul State Theater). According to Ishil Casapoglu, the director of the play, the work on Shakespeare's text was full of emotions, new assets, new experiences: "There is a lot to learn from the actors and the whole directing team from Shakespeare and we are going this way" ${ }^{, 52}$.

In 2013, director Gulschah Ozdemir Korkyurek presented to the public a short documentary film Being Shakespeare in Turkey, which begins with the symbolic phrase: "To be or not to be?"53 There have been many reviews of this film in Turkish newspapers and to this day almost every year, this film is presented at various festivals and cultural events.

\section{CONCLUSIONS}

The Turkish cultural sphere, having a strong centuries-old eastern background, opened the door to the West in the 19th century, allowing most currents, directions, and cultural changes to affect the Ottoman state, and later the Turkish Republic. For two centuries, Turkish culture has been catching up, developing, applying in its fields what has been characteristic of Western trends. Analyzing the enormous positive impact of Western literature on Turkish literature, we can safely say that the interaction of Eastern and Western cultures, in this case, has the most positive effects. Acquaintance of the Turkish nation with the works of French, English, German, Slavic authors opened new literary possibilities, new trends for Turkey, directions, types of literature, a new vision of the world.

An important role in this cultural interaction was played by the individual, the creator of all times, for all peoples - Shakespeare. The material presented in this study demonstrates the depth of Shakespeare's word penetration into the Turkish cultural space, from the dramatic sphere to the scientific and media sphere.

Turkish dramaturgy opens new possibilities for literary and stage interpretation of Bard, enriched in the perception of Shakespeare's word. The emergence of a dramatic discourse on Turkey, in particular in

${ }^{52}$ Kasapoğlu I. Hamlet, Dümeni kırık gemi misali rüzgara göre yön alıyor. Arka Kapak Kitap ve Kültür dergisi. Mayıs 2018, sayı 32. S. 39.

${ }^{53}$ Avc1 Z. Şekspir'den Shakespeare'e. 
children's dramaturgy, of the tendency to approach Shakespeare proves once again that his creativity is an inexhaustible source of humanism, democracy and the truth of life that have no national or religious boundaries. The functioning of Shakespeare's image and his work in other than Turkey's cultural spheres asserts the fact that the Turkish nation, both older and younger, knows and honors Bard, is familiar with his texts at almost a subconscious level and continues to promote his creativity, creating new plays, films, prose interpretations.

\section{SUMMARY}

The article is devoted to the study of the functioning of Shakespeare's image and his work in the Turkish cultural space. The focus is on the stages of Shakespeare's entry into Turkish culture primarily translations from French, later English, artistic interpretations of famous Turkish authors (stories, novels), stage adaptations of Turkish directors. Particular attention is focused on the scientific and media space of Turkey, in which Shakespeare's creative work is quite versatile. The results of the study prove that the Turkish nation is well aware of Shakespeare's works since the 19th century and to this day the creativity of the Bard is widely represented in Turkish culture, a new generation of the Turkish community trying to instill a love for Shakespeare, affirming the immortality of his thoughts and ideas.

Keywords: Shakespeare's literary works, adaptations, translation, Turkish culture, dramaturgy, media space.

\section{REFEFENCES}

1. Прушковська I. В. “Краса і Любов” Шейха Галіба (до проблеми індійського стилю у турецькій літературі) [Монографія]. Київ, 2008. 256 с.

2. Торкут Н. М. Шекспірознавчий дискурс XX століття: специфіка і тенденції. Ренесансні студії. Запоріжжя, 2003. Вип. 9. C. 65-74.

3. Aldağ Z. Ş. Türk tiyatrosunda Kurtuluş savaşı İ̀stanbul, 2008. $400 \mathrm{~s}$.

4. And M. Osmanlı tiyatrosu kuruluşu gelişimine katkısı. Ankara, 1976. $280 \mathrm{~s}$.

5. Avcı Z. Şekspir'den Shakespeare'e: Üstadın Anadolu macerası. BBC Türkçe, 7 Mayıs 2014. URL: http://www.bbc.com/turkce/ haberler/2014/05/140507_shakespeare_anadolu_zeynep_avci. 
6. Ayluçtarhan S. Dr. Abdullah Cevdet's translations (19081910): The making of materialist "culture repertoire" in a resistant ottoman context: Thesis master of arts in translation studies. İstanbul, 2007. $248 \mathrm{~s}$.

7. Baydur M. Tiyatro oyunları. İstanbul, 2009. $869 \mathrm{~s}$.

8. Çeşitli İ. II. Meşrutiyet dönemi Türk edebiyatı. Ankara, 2007. $639 \mathrm{~s}$.

9. Cumal1 N. Bütün oyunlar1 2. İstanbul, 2004. $1085 \mathrm{~s}$.

10. Duman O. Bir Yaz Gecesi Rüyası ve Bahar Noktası'nın çeviri açısından karşılaştırılması. Çeviriblog. URL: https://www.ceviriblog.com/ 2016/08/30/bir-yaz-gecesi-ruyasi-ve-bahar-noktasinin-ceviri-acisindan-ka rsilastirilmasi/.

11. Enginün İ. Tanzimat devrinde Shakespeare: Tercümeleri ve tesiri. Istanbul, 1979. $326 \mathrm{~s}$.

12. Enginün İ. Türkçede Shakespeare. İstanbul, 2008. 527 s.

13. Grip aş1s1 olmak ya da olmamak, işte bütün mesele bu! 27 Ekim 2017, Cuma. URL: https://www.haberaramizda.com/grip-asisiolmak-ya-da-olmamak.html.

14. Güner O. Toplu oyunları 1. İstanbul, 1996. $95 \mathrm{~s}$.

15. Karataş H. Türkiye'de Hamlet olmak. Arka Kapak Kitap ve Kültür dergisi. Mayıs 2018, sayı 32. S. 34-37.

16. Kasapoğlu I. Hamlet, Dümeni kırık gemi misali rüzgara göre yön alıyor. Arka Kapak Kitap ve Kültür dergisi. Mayıs 2018, sayı 32. S. 38-41.

17. Nutku Ö. Bana William Deyin. İstanbul, 2011. $56 \mathrm{~s}$.

18. Şener S. Cumhuriyet'in 75 yılında Türk tiyatrosu. Ankara, 1998. $331 \mathrm{~s}$.

19. Shakespeare W. Bahar Noktası. Türkçe söyleyen Can Yücel. İstanbul, 1981. $80 \mathrm{~s}$.

20. Shakespearebistro. Мепи. URL: http://shakespearebistro.com/.

21. Torbalı Ö. Y. Çeviri ve tarihsel hafıza. Çeviribilimde Güncel Tartışmalardan Kavramsal Sorgulamalara Monografi. İstanbul, 2018. S. 15-247.

22. Türkeş A. Ö. Darbeler; Sözün Bittiği Zamanlar. Hece Hayat, Edebiyat, Siyaset. İstanbul, 2004. Özel Say1s1: S. 90/91/92. S. 426-434.

23. Uslu N. Firtına (W. Shakespeare). Çocuk oyunu. İstanbul, 2015. $68 \mathrm{~s}$. 
24. Varlı Ö. Zorlu 90 dakika iki takımın da kaderini belirleyecek Olmak ya da Olmamak. AkdenizManşet. 5.03.2019. URL: https:// www.akdenizmanset.com.tr/spor/olmak-ya-da-olmamak/157138/.

25. 12 Eylül ve Edebiyat. 12.09.2009. URL: http:// www.sabitfikir.com/dosyalar/12-eylul-ve-edebiyat.

Information about the author:

Prushkovska Iryna Vitaliivna.

Doctor of Philology, Associate Professor, Associate Professor of Foreign Languages Department of Taras Shevchenko National University of Kyiv. Illenka str. 36/1, Kyiv, Ukraine,02225 